\title{
PERSEPSI MASYARAKAT TERHADAP KEBERADAAN HUTAN KEMASYARAKATAN DI DESA LUBUK KERTANG KECAMATAN BRANDAN BARAT KABUPATEN LANGKAT
}

\author{
PERCEPTION OF COMMUNITIES ON THE EXISTENCE OF COMMUNITY \\ FORESTS IN THE VILLAGE OF LUBUK KERTANG SUB-DISTRICT BRANDAN \\ BARAT, LANGKAT REGENCY
}

Fajar Ahmadi Depari ${ }^{1}$, Martunis ${ }^{1}$, Ryan Moulana $^{1 *}$

${ }^{1}$ Program Studi Kehutanan, Fakultas Pertanian, Universitas Syiah Kuala

Email: ryanmoulana@gmail.com

\begin{abstract}
Abstrak. Hutan Kemasyarakatan ialah kawasan hutan negara yang ditujukan kepada masyarakat setempat pemanfaatannya, bertujuan meningkatkan kesejahteraan masyarakat setempat melalui pemanfaatan sumberdaya alam ataupun sumberdaya hutan secara berkelanjutan, optimal dan adil dengan cara tetap menjaga fungsi lingkungan hidup dan hutan. Adapun tujuan ialah mengetahui persepsi dari masyarakat terhadap keberadaan Hutan Kemasyarakatan dan jugafaktor mempengaruhinya.Persepsi responden diukur dengan membagikan kuesioner dan dianalisa. Persepsi dari masyarakat tergolong tinggi pada aspek ekologi dan ekonomi.
\end{abstract}

Kata kunci: Hutan Kemasyarakatan

\begin{abstract}
Abstrac. Community forestry is a state forest area aimed at the local community for its use, aiming to improve the welfare of the local community through the sustainable, optimal and fair use of natural resources or forest resources by maintaining the environmental and forest functions. The purpose of this study was to determine people's perceptions of the existence of the Community Forest and the factors that influence it. Measurement of respondents' perceptions was carried out by interview using a questionnaire and field observations which were then analyzed. The level of public perception is high in ecological and economic aspects.
\end{abstract}

Keywords: Community forestry 


\section{PENDAHULUAN}

Hutan adalah sumberdaya alam yang menyediakan manfaat yang cukup besar untukkehidupan manusia, baik manfaat yang dirasakan secara langsung, ataupunyang dirasakan secara tidak langsung. Manfaat langsung seperti penyedia kayu, sumber keanekaragaman hayati,perlindungan. Sedangkan manfaat tidak langsung seperti pengatur siklus air, penyerap dan menyimpan karbon. Keberadaan hutan dapat ditentukan berapa tinggi kesadaran pada masyarakat akan arti penting hutan dalam memanfaatkan dan mengelola hutan. Hutansebagai media hubungan timbalbalik antara manusia dan makhlukhidup lainnya (Reksohadiprojo, 2000).

Sari, (2012) Pada studi terhadap kerusakan Ekosistem mangrove di Desa Lubuk Kertang melaporkan bahwa lebih dari $740 \mathrm{Ha}$ atau 61,67\% kawasan hutan mangrove berada dalam kondisi rusak, penyebab utama kerusakan mangrove adalah tekanan penduduk untuk memenuhi kebutuhan ekonomi melalui konversi lahan untuk membuka tambak dan perkebunan kelapa sawit. Salah satu upaya pemerintah untuk mempertahankan dan meningkatkan pemanfaatan kawasan hutan secara lestari adalah menerapkan perhutanan sosial dengan menjadikan kawasan hutan tersebut sebagai Hutan Kemasyarakaatan. Hutan Kemasyarakatan atau biasa disebut dengan HKM merupakan salah satu bentuk perhutanan sosial. Umumnya Perhutanan sosial sebagai kebijakan atau payung yang mencakup program dan kegiatan kehutanan yang banyak ataupun sedikit melibatkan peranan masyarakat ataupun penduduk sekitar, dan dikembangkan untuk kesejahteraan masyarakat (Suharjito, 2000).

Masyarakat di sekitar hutan kemasyarakatan merupakan faktor terpenting bagi berhasilnya pengelolaan hutan kemasyarakatan yang lestari. Masyarakat yang juga merupakan bagian dari ekosistem sekitar hutan kemasyarakatan akan berusaha untuk mendapatkan manfaat yang diberikan oleh hutan kemasyarakatan. Hasilnya tidak selalu menguntungkan kedua belah pihak, melainkan merugikan seperti eksploitasi secara illegal. Hal ini tergantung dari bagaimana persepsi masyarakat dalam mengelola hutan kemasyarakatan.Oleh karena itu, penelitian tentang persepsi masyarakat sekitar terhadap keberadaan hutan kemasyarakatan perlu dilakukan. 


\section{METODE PENELITIAN}

\section{Tempat dan Waktu Penelitian}

Penelitian akan dilakukan di Desa Lubuk Kertang Kecamatan Brandan Barat Kabupaten Langkat Provinsi Sumatera Utara. Penelitian berlangsung mulai dari bulan September sampai dengan bulan November 2019.

\section{Alat dan Bahan Penelitian}

Alat dan Bahan yang digunakan dalam penelitian ini adalah alat tulis, kamera dan angket/kuisioner.

\section{Teknik Pengambilan Data}

Pengambilan data dilakukan dengan cara menjalankan kuesioner dan studi pustaka.

Populasi dan Sampel

Populasi yang akan diteliti yaitu sebanyak 1.134 orang kepala keluarga (1.134) diambil sebagai sampel sebanyak 10\% sehingga jumlah responden sebanyak $113 \mathrm{KK}$, yang dipilih berdasarkan simple random sampling, berdasarkan Arikunto (1998) jika populasi relatif kecil atau kurang dari 100 orang maka keseluruhan populasi dijadikan sebagai sampel, namun jika populasi relatif besar atau lebih dari 100 orang, maka penarikan sampel dilakukan sebanyak 10\%-30\% dari populasi tersebut.

Kuisioner

Kuisioner berisikan sekumpulan pertanyaan yang di tujukan kepada reponden dalam penelitian.
a. Karakteristik responden adalah tingkat Pendidikan, pekerjaan dan umur
b. Sejumlah pertanyaan yang berkaitan dengan persepsi masyarakat 


\section{Metode Olah dan Analisis Data}

Persepsi Masyarakat

Penilaian persepsi masyarakat terhadapkeberadaan Hutan Kemasyarakatan ini menggunakan bantuan skoring.Penentuan skoring dilakukan dengan sistem penilaian "Skala Likert".Penilaian dengan memberi soal kepada responden dengan pilihan jawaban "Sangat tahu, Tahu, Tidak tahu, Sangat tidak tahu.Jawaban ini diberi skor 4,3,2,1 secara berurutan.Kemudian skor di rubah dalam bentuk skala. Skala ditentukan Intervalnya terlebih dahulu, seperti dibawah :

$$
\begin{gathered}
\text { interval }=\frac{\text { Bobot nilai tertinggi }- \text { Bobot nilai terendah }}{\text { Banyaknya kelas }} \\
\text { interval }=\frac{4-1}{4}=0,75
\end{gathered}
$$

Setelah interval didapatkan kemudian di buat skala sebagai berikut :

Tabel 1. Skala interval tanggapan

\begin{tabular}{|c|c|}
\hline Interval nilai tanggapan & Tingkat persepsi \\
\hline $3.26-4.00$ & Sangat tinggi \\
$2.51-3.25$ & Tinggi \\
$1.76-2.50$ & Rendah \\
$1.00-1.75$ & Sangat rendah \\
\hline
\end{tabular}

Pertanyaan yang digunakan untuk mengukur persepsi masyarakat adalah mengenai dampak yang ditimbulkan oleh hutan kemasyarakatan yang mencakup aspek ekologi,ekonomi dan kebijakan. Data yang didapat dari kuesioner kemudian di cari nilai total skor dengan menjumlahkan dari setiap nilai yang di dapat dari responden.

Analisis faktor-faktor berpengaruh pada persepsi

Hasil dari kuesioner di olah menggunakan analisis korelasi yaitu Rank Spearman dan analisis deskriptif dengan memakai aplikasi SPSS 20 FORWINDOWS dikarenakan data 
dalam bentuk data yangkuantitatif. Analisis deskriptif digunakan bertujuan mendeskripsikan variabel bebas dan variabel tergantung dalam skala nominal.

Analisis korelasi Rank Spearman digunakan untuk mengetahaui ada atau tidak hubungan antar kedua variablel dalam skala ordinal (non parametik) rumus korelasi ini adalah:

$$
r s=1-\frac{6 \sum d^{2}}{n\left(n^{2}-1\right)}
$$

Keterangan $\quad \mathrm{rs}=$ Kolerasi Spearman $\quad d^{2}=$ selisih antara variable $\mathrm{x}$ dan $\mathrm{y}$

$$
\begin{aligned}
& \mathrm{X}=\text { Tingkat pendidikan, pekerjaan dan umur } \quad \mathrm{Y}=\text { Persepsi } \\
& \mathrm{n}=\text { banyaknya pasang data }
\end{aligned}
$$

Supaya dapat ditafsirkan dengan ketentuan yang di tentukan, diperlukan kategori atau kriteria kuat atau lemah hubungan. (Sarwono,2006). yang dapat dilihat pada tabel dibawah :

Tabel 2. Korelasi Interval

\begin{tabular}{|c|c|}
\hline Interval & Tingkat Korelasi \\
\hline $0-0,25$ & sangat lemah \\
$0.26-0.50$ & cukup \\
$0.51-0.75$ & kuat \\
$0.76-0.99$ & sangat kuat \\
1 & sempurna \\
\hline
\end{tabular}

Setelah dilihat korelasi kemudian dibuat kesimpulan diterima atau ditolak.

Ho adalah tidak ada hubungan yang signifikan, $\mathrm{H} 1$ adalah ada hubungan yang signifikan.

Tabel 3. Karakteristik

\begin{tabular}{|c|c|c|c|}
\hline \multirow{2}{*}{ Faktor Internal } & Klasifikasi & Jumlah & Persentase(\%) \\
\hline \multirow{2}{*}{ Usia/Umur } & 1. $<25$ tahun. & 1 & \\
& 2. 25-35 tahun. & 2 & $\%$ \\
& 3. 36-45 tahun. & 4 & \\
& 4. > 45 tahun. & & \\
\hline
\end{tabular}




\begin{tabular}{|c|c|c|c|}
\hline Tingkat Pendidikan & $\begin{array}{l}\text { 1. Sekolah Dasar (SD) } \\
\text { 2. Sekolah Menengah (SMP) } \\
\text { 3. Sekolah Menengah (SMA) } \\
\text { 4. Perguruan Tinggi }\end{array}$ & $\begin{array}{l}1 \\
2 \\
3 \\
4\end{array}$ & $\%$ \\
\hline Pekerjaan Pokok & & & $\%$ \\
\hline Jarak Rumah Ke Hkm & $\begin{array}{l}\text { 1. Sangat Dekat }(0-1 \mathrm{~km}) \\
\text { 2. Dekat }(>1 \mathrm{~km}-2 \mathrm{~km}) \\
\text { 3. Jauh }(>2 \mathrm{~km}-4 \mathrm{~km}) \\
\text { 4. Sangat Jauh }(>4 \mathrm{~km})\end{array}$ & $\begin{array}{l}1 \\
2 \\
3 \\
4\end{array}$ & $\%$ \\
\hline Jumlah tanggungan & $\begin{array}{ll}\text { 1. } & 0 \text { orang } \\
\text { 2. } & 1 \text { orang } \\
\text { 3. } & \text { 2orang } \\
\text { 4. } & \text { 3orang atau lebih }\end{array}$ & $\begin{array}{l}1 \\
2 \\
3 \\
4\end{array}$ & $\%$ \\
\hline Pendapatan & $\begin{array}{ll}\text { 1. } & <\mathrm{Rp} 1 \mathrm{jt} \\
\text { 2. } & >\mathrm{Rp} 1 \mathrm{jt}-\mathrm{Rp} 2 \mathrm{jt} \\
\text { 3. } & >\mathrm{Rp} 2 \mathrm{jt}-\mathrm{Rp} 3 \mathrm{jt} \\
\text { 4. } & >\mathrm{Rp} 3 \mathrm{jt}\end{array}$ & $\begin{array}{l}1 \\
2 \\
3 \\
4\end{array}$ & $\%$ \\
\hline Jenis kelamin & & & $\%$ \\
\hline Status keanggotaan & & & $\%$ \\
\hline
\end{tabular}

\section{HASIL DAN PEMBAHASAN}

\section{Persepsi Masyarakat}

Persepsi ialah Sudut pandang atau pengertian ataupun satu kesan terhadap objek, dari areal atau lingkungan. Sedangkan Rakhmat (2005), menyimpulkan persepsi pengalaman terhadap objek dengan apapun yang diperoleh dan mengartikan informasi.

Tingkat persepsimasyarakat terhadap ekologi di dominasi pada kategori "tinggi" yaitu sebanyak 42 orang responden atau 37\%. Masyarakat turut menjaga kelestarian ekosistem mangrove dengan tidak merambah dan merusak, anggota dari kelompok hutan kemasyarakatan memiliki tingkat pengetahuan terhadap ekologi yang cukup tinggi. Sebagian besar dari masyarakat kurang mengetahui fungsi mangrove sebagai pengurai bahan kimia 
seperti limbah yang dibuang ke air laut, berikut dapat dilihat persentase persepsi ekologi pada gambar dibawah.

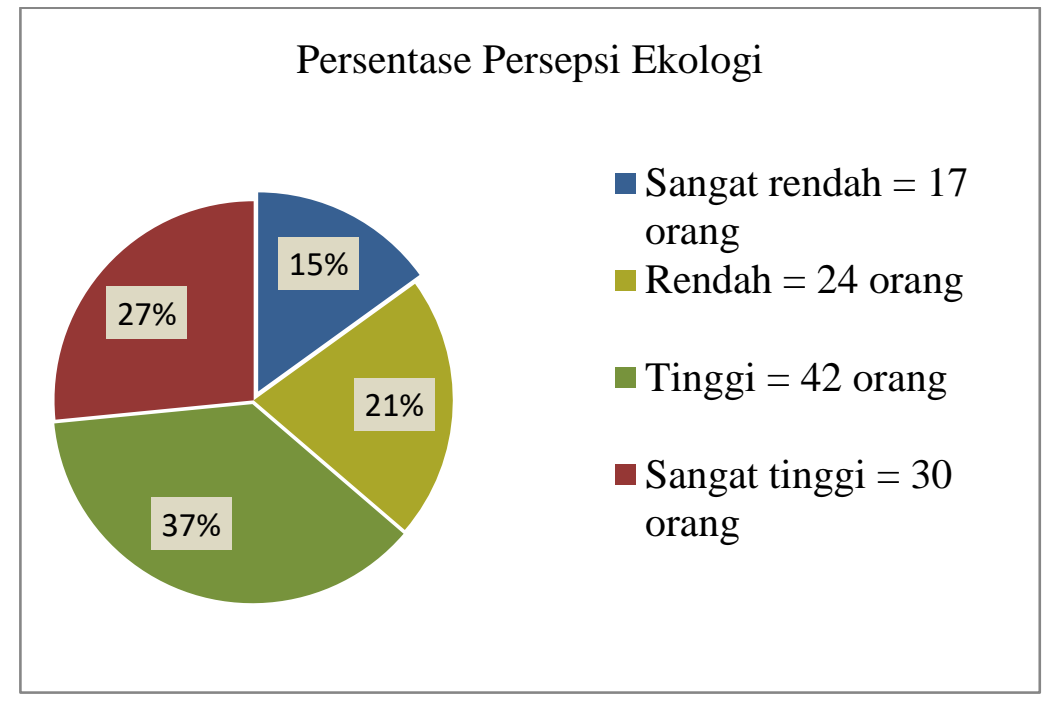

Dari gambar di atas dapat dilihat Persentase dengan jawaban sangat rendah sebanyak 17 orang (15\%), sedangkan persentase dengan jawaban rendah sebanyak 24 orang (21\%). Dan dengan persentase jawaban responden dalam kategori tinggi sebanyak 42 orang (37\%), sedangkan persentase jawaban dengan kategori sangat tinggi sebanyak 30 orang responden $(27 \%)$. Adapaun total keseluruhan responden yaitu sebanyak 113 orang. Seperti yang dapat dilihat persentase dengan kategori jawaban rendah dan sangat rendah pada persepsi ekologi sejumlah 41 orang $(36 \%)$, dan hal ini disebabkan karena kurangnya tingkat kepedulian responden terhadap ekologi sehingga responden tidak mendapatkan informasi dan tidak memahami fungsi penting dari ekosistem mangrove. Sedangkan 72 responden (64\%) memiliki persentase jawaban dengan kategori tinggi dan sangat tinggi.

Adapun yang memiliki persepsi tinggi adalah responden yang memiliki kepedulian terhadap ekosistem mangrove dan merasakan manfaat seperti menjaga sirkulasi udara dan penahan terpaan angin .Sehingga mendapatkan informasi yang diberikan oleh Permerintah ataupun Lembaga Swadaya Masyarakat (LSM) melalui berbagai penyuluhan. Hal tersebut sama dengan Heru Setiawan (2017), persepsi masyarakat mengenai mangrove $94.35 \%$ responden menyatakan setuju dan mengetahui fungsi mangrove, merupakan tempat 
berkembangnya biota laut dan penahan angin, ombak dan abrasi. 5,65\% responden menyatakan tidak memahami fungsi ekologi mangrove.

\section{Hubungan Faktor Internal Dengan Persepsi masyarakat}

Responden yang terpilih pada penelitian ini sejumlah 113 orang yang tinggal di Desa Lubuk Kertang.Faktor yang muncul dari diri seseorang adalah faktor internal, faktor internal dapat mempengaruhi pola fikir terhadap suatu objek atau permasalahan (Budiarti 2011). Faktor internal yang di duga berhubungan dengan persepsi adalah Umur, Pendidikan, Pekerjaan, Jumlah tanggungan, Jarak tempat tinggal, Jenis kelamin dan Keanggotan kelompok.Persepsi responden yang diolah diuji dengan analisis korelasi Rank Spearman menggunakan software SPSS 22 dan analisis deskriptif. Berikut dapat dilihat faktor internal atau karakteristik responden pada tabel dibawah.

Tabel 4. Karakteristik responden terpilih

\begin{tabular}{|c|c|c|c|}
\hline Faktor Internal & Klasifikasi & Jumlah & $\begin{array}{c}\text { Persentase } \\
(\%)\end{array}$ \\
\hline Usia/Umur & $\begin{array}{l}1 .<25 \text { tahun } \\
\text { 2. } 25-35 \text { tahun } \\
\text { 3. } 36-45 \text { tahun } \\
\text { 4. }>45 \text { tahun }\end{array}$ & $\begin{array}{c}18 \\
48 \\
18 \\
29\end{array}$ & $\begin{array}{l}16 \\
42 \\
16 \\
26\end{array}$ \\
\hline Tingkat Pendidikan & $\begin{array}{ll}\text { 1. } & \text { SD } \\
\text { 2. } & \text { SMP } \\
\text { 3. } & \text { SMA } \\
\text { 4. } & \text { Perguruan Tinggi }\end{array}$ & $\begin{array}{c}6 \\
26 \\
69 \\
12\end{array}$ & $\begin{array}{c}5 \\
23 \\
61 \\
11\end{array}$ \\
\hline Pekerjaan Pokok & $\begin{array}{l}\text { Petani } \\
\text { Nelayan } \\
\text { PNS } \\
\text { Wiraswasta } \\
\text { Wirausaha } \\
\text { Irt/Pensiunan }\end{array}$ & $\begin{array}{c}33 \\
19 \\
8 \\
17 \\
2 \\
34\end{array}$ & $\begin{array}{c}29 \\
17 \\
7 \\
15 \\
2 \\
30\end{array}$ \\
\hline Jarak Rumah Ke Hkm & $\begin{array}{ll}\text { 5. } & \text { Sangat Dekat }(0-1 \mathrm{~km}) \\
\text { 6. } & \text { Dekat }(>1 \mathrm{~km}-2 \mathrm{~km}) \\
\text { 7. } & \text { Jauh }(>2 \mathrm{~km}-4 \mathrm{~km}) \\
\text { 8. } & \text { Sangat Jauh }(>4 \mathrm{~km})\end{array}$ & $\begin{array}{l}11 \\
60 \\
42\end{array}$ & $\begin{array}{l}10 \\
53 \\
37\end{array}$ \\
\hline
\end{tabular}




\begin{tabular}{|l|l|c|c|}
\hline & & 0 & 0 \\
\hline Jumlah tanggungan & 1. 0 orang & 34 & 30 \\
& 2. 1 orang & 18 & 16 \\
& 3. 2orang & 24 & 21 \\
& 4. 3orang atau lebih & 37 & 33 \\
& & & \\
\hline Pendapatan & $1 . \quad<\mathrm{Rp} 1 \mathrm{jt}$ & 46 & 41 \\
& $2 .>\mathrm{Rp} 1 \mathrm{jt}-\mathrm{Rp} 2 \mathrm{jt}$ & 40 & 35 \\
& $3 .>\mathrm{Rp} 2 \mathrm{jt}-\mathrm{Rp} 3 \mathrm{jt}$ & 23 & 20 \\
& $4 . \quad>\mathrm{Rp} 3 \mathrm{jt}$ & 4 & 4 \\
& & & \\
\hline Jenis kelamin & Permpuan & 51 & 45,36 \\
& Laki-laki & 62 & 54,64 \\
\hline Keanggotaan kelompok & Anggota kelompok & 40 & 35.40 \\
& Bukan anggota kelompok & 73 & 64.60 \\
\hline
\end{tabular}

Faktor internal yang dapat diuji dengan metode Rank Spearman adalah Usia, Tingkat pendidikan, Pendapatan, Jumlah tanggungan keluarga dan Jarak dari tempat tinggal ke hutan kemasyarakatan. Data yang di uji pada analisis deskriptif adalah data nominal, Faktor internal responden yang menghasilkan data nominal adalah jenis pekerjaan, jenis kelamin, dan keanggotaan kelompok.Berikut dapat dilihat peubah yang diduga dapat mempengaruhi persepsi yang diuji dengan analisis korelasi Rank Spearman pada tabel dibawah.

Tabel 5. Korelasi

\begin{tabular}{|c|c|c|c|c|c|}
\hline \multirow{2}{*}{$\begin{array}{c}\text { Persepsi } \\
\text { masyarakat }\end{array}$} & \multicolumn{5}{|c|}{ Variabel faktor internal } \\
\hline & Usia & $\begin{array}{c}\text { Tingkat } \\
\text { pendidikan }\end{array}$ & Jarak & Tanggungan & Pendapatan \\
\hline Aspek Ekologi & $0.310 * *$ & -0.006 & $-0.578 * *$ & $0.358 * *$ & $0.308 * *$ \\
\hline
\end{tabular}

Adapun korelasi yang memiliki tanda $(* *)$ atau $(*)$ adalah korelasi yang memiliki hubungan atara kedua variabe dan signifikan, semakin kecil nilai signifikansi maka korelasi semakin signifikan.Tanda $(* *)$ menunjukkan signifikansi korelasi pada taraf $(0.01)$ sedangkan tanda (*) menunjukkan signifikansi korelasi pada taraf (0.05). Sedangkan arah hubungan kedua variabel dapat dilihat besar korelasi. Jika nilai positif maka hubungan 
searah, sedangkan jika nilai korelasi negaif maka dinyatakan hubungan tidak searah namun berkorelasi.Berikut dapat dilihat penjelasan faktor internal atau karakteristik responden dan hubungan antara faktor internal atau karakteristik responden dengan persepsi ekologi.

\section{Usia}

Hasil dari uji korelasi rank spearman faktor internal usia dengan aspek ekologi memiliki hubungan signifikansi dengan nilai Sig. (2-tailed) (0.01) dengan besar korelasi $0.310^{* *}$, Korelasi positif tersebut menunjukkan bahwa antara faktor internal usia dengan persepsi ekologi memiliki hubungan yang searah. jumlah bilangan korelasi 0.310 artinya “cukup", dapat dilihat pada parameter pada tabel 2 interval koefisien korelasi. Maka tolak Ho dan terima H1 artinya hubungan antara umur dengan persepsi ekologi berpengaruh nyata. Semakin tinggi usia maka masyarakat semakin sadar akan pentingnya fungsi ekologi hal tersebut dikarenakan responden yang memiliki usia tinggi lebih memiliki pengalaman dan dapat membandingkan perbedaan pada saat rusaknya mangrove dengan saat pulihnya mangrove, baik pada kehidupan sehari-hari ataupun pendapatan mereka . Namun hal ini berbeda dengan Pernyataan Agam Wesley (2016) yang menyatakan usia dengan persepsi ekologi tidak memiliki hubungan yang nyata, pada penelitian persepsi masyarakat terhadap keberadaan Taman Wisata Alam Sibolangit.

\section{Tingkat Pendidikan}

Hasil dari uji korelasi rank spearman faktor internal tingkat pendidikan dengan persepsi ekologi memiliki nilai signifikansi Sig.(2-tailed) (0.947) dan nilai korelasi -0.006, maka terima Ho tolak H1 artinya tidak ada hubungan yang nyata antara tingkat pendidikan dengan persepsi ekologi. Nilai korelasi negatif menunjukkan hubungan tidak searah. Hal ini disebabkan masyarakat yang memiliki pendidikan tinggi harus meninggalkan desa Lubuk Kertang untuk melanjutkan pendidikan, hal tersebut dikarenakan masih minimnya sarana dan infrastruktur pendidikan untuk tingkat lanjut. Oleh karena itu masyarakat yang melanjutkan penddidikan keluar daerah kurang mendapatkan informasi dan kurang antusias terhadap keberadaan mangrove dan areal HKm. Mimi Salminah (2014), walaupun tingkat pendidikan masyarakat pada areal Daerah aliran sungai batu rusa dan Cidanau cenderung sama yaitu 
Sekolah dasar, namun berdasarkan pengamatan di lapangan masyarakat memiliki kepedulian yang tinggi terhadap konservasi hutan semenjak sering terjadinya banjir dan longsor di daerah hulu Daerah aliran sungai cidanau di masa lalu, serta sulitnya mengolah areal hutan menjadi penggunaan lain seperti areal pertanian, atau areal permukiman.

\section{Jarak Tempat Tinggal ke Areal Hutan Kemasyarakatan}

Berdasarkan hasil analisis korelasi rank spearman, faktor internal jarak tempat tinggal ke HKm dengan persepsi ekologi memiliki nilai signifikansi Sig.(2-tailed) (0.000) dan dengan nilai korelasi adalah $-0.578^{* *}$. Maka tolak Ho dan terima H1 artinya faktor internal jarak dengan persepsi ekologi memiliki hubungan yang nyata. Nilai koefisien korelasi negatif menunjukkan hubungan tidak searah dan korelasi berada pada kategori "kuat". Sahid raharjo (2014) menyatakan, besarnya nilai hubungan antara +1 sampai dengan -1 . Jika nilai korelasi negatif artinya tidak searah, maka semakin dekat jarak rumah responden dengan areal HKm semakin tinggi persepsi msayarakat terhadap persepsi ekologi, hal tersebut dikarenakan masyarakat yang berada dekat dengan hutan kemasyarakatan adalah masyarakat yang merasakan dampak langsung dari keberlangsungan ekologi mangrove.. Nesmi Puspitasari (2017), persepsi ekologi masyarakat marunda pulo yang tinggi untuk mengetahui restorasi ekologi hutan mangrove. hal ini dikarenakan kondisi daya dukung lingkungan pada desa marunda pulo yang semkin kecildikarenakan pengaruh kerusakan alam secara terus menerus yang mampu menjadikan alasan masyarakat untuk mengetahui lebih jelas mengenai penjelasan tentang ekologi mangrove tersebut.

\section{Jumlah Tanggungan}

Faktor internal jumlah tanggungan responden dengan persepsi keberadaan HKm memiliki hubungan yang signifikan. Persepsi ekologi memiliki nilai Sig.(2-tailed) (0.000). Tolak Ho dan terima H1 artinya hubungan nyata, dengan besar korelasi $0.358^{* *}$. Artinya hubungan searah dan berada pada kategori "cukup" berpengaruh. Semakin banyak jumlah tanggungan responden, maka semakin berfikir akan pentingnya ekosistem mangrove yang berkelanjutan untuk anak cucu kelak. 


\section{Pendapatan}

Dari hasil analisis faktor internal pendapatan dengan persepsi ekologi memiliki hubungan signifikansi Sig.(2-tailed) (0.001). Tolak Ho dan terima H1 artinya pendapatan responden dan persepsi ekologi memiliki hubungan yang nyata dan signifikan, dengan besar koefisien korelasi $0.308^{* *}$. Artinya hubungan searah dan cukup berpengaruh, besar korelasi jumlah tanggungan menunjukkan hubungan yang "cukup", semakin tinggi pendapatan maka akan semakin tinggi persepsi ekologi responden. Surati (2014) bahwa semakin tinggi pendapatan seseorang perilakunya akan bertambah positif, karena dengan pendapatan yang lebih tinggi maka seseorang akan lebih mempunyai kesempatan untuk mendapatkan informasi termasuk informasi hutan dan pengelolaannya.

Tabel 6. Persentase Persepsi

\begin{tabular}{|c|c|c|c|c|c|c|c|c|c|c|}
\hline \multirow{2}{*}{$\begin{array}{c}\text { Persepsi } \\
\text { Masyarakat }\end{array}$} & \multicolumn{5}{|c|}{ Perkerjaan (\%) } & \multicolumn{2}{c|}{$\begin{array}{c}\text { Keanggotaan } \\
(\%)\end{array}$} & $\begin{array}{c}\text { Jenis Kelamin } \\
(\%)\end{array}$ \\
\cline { 2 - 10 } & IRT & Petani & PNS & $\begin{array}{c}\text { Wira } \\
\text { swasta }\end{array}$ & $\begin{array}{c}\text { Wira } \\
\text { usaha }\end{array}$ & Nelayan & Kelompok & $\begin{array}{c}\text { Bukan } \\
\text { Kelompok }\end{array}$ & $\begin{array}{c}\text { Laki- } \\
\text { laki }\end{array}$ & $\begin{array}{c}\text { Perem } \\
\text { puan }\end{array}$ \\
\hline Ekologi & 51.23 & 53.63 & 54.25 & 54.35 & 43 & 66.21 & 62.35 & 50.95 & 58.29 & 50.98 \\
\hline
\end{tabular}

\section{Pekerjaan Pokok}

Tabel di atas di dominasi oleh Irt sebanyak 34 orang (30\%) karena pada Desa Lubuk Kertang di dominasi oleh laki-laki sebagai pencari nafkah dapat dilihat jumlah ibu rumah tangga sebanyak 812 orang pada Desa Lubuk Kertang. Di ikuti dengan responden yang pekerjaan sebagai Petani sebanyak 33 orang (29\%), Nelayan sebanyak 19 orang (17\%), Wiraswasta sebanyak 17 orang (15\%), PNS sebanyak 8 orang (7\%) dan Wirausaha sebanyak 2 orang $(2 \%)$. 


\section{Ibu Rumah Tangga}

Irt memiliki persepsi ekologi pada (51.23\%). Responden ini menilai keberadaan hutan kemasyarakatan mangrove dapat berperan penting dalam menjaga kulitas udara dan sebagai tempat habitat hewan.

Petani

Responden yang bekerja sebagai petani memiliki persepsi ekologi (53.63\%). Masyarakat yang bekerja sebagai petani memiliki persepsi baik terhadap ekologi

PNS

Responden yang bekerja sebagai PNS memiliki persepsi ekologi pada (54.25\%). Tingkat persepsi PNS pada aspek ekologi cukup baik dikarenakan pemahaman terhadap mangrove memiliki fungsi penting sebagai pengatur kualitas udara.

\section{Wiraswasta}

Responden yang bekerja sebagai wiraswasta memiliki persepsi ekologi (54.35\%). Sama halnya dengan PNS, yang memliki profesi sebagai wiraswasta

Wirausaha

Responden yang bekerja sebagai wirausaha memiliki persepsi ekologi pada (43\%)

Nelayan

Responden yang bekerja sebagai nelayan memiliki persepsi paling tinggi pada aspek ekologi (66.21\%), Nelayan Desa Lubuk Kertang sempat mengalami sulitnya mendapatkan ikan dikarenakan rusaknya ekosistem mangrove dan mulai membaik saat ekosistem mangrove setelah pulih kembali. Nelayan Desa Lubuk Kertang tidak memanfaatkan kawasan hutan kemasyarakatan mangrove untuk memenuhi krebutuhan mereka.

\section{Keanggotaan}

Responden yang merupakan anggota kelompok hutan kemasyarakatan memiliki pesepsi pada aspek ekologi (62.35\%) Responden yang merupakan anggota kelompok memiliki 
pemahaman yang baik terhadap keberadaan hutan kemasyarakatan, baik dari segi ekologi kebijakan maupun ekonomi.

Jenis kelamin

Respoden Perempuan dan Laki-laki memiliki yang tinggi yaitu aspek ekologi (58.29\%) dan $(50.98 \%)$, Masyarakat pada umumnya mengetahui fungsi mangrove sebagai pengatur kualitas udara, dan juga sebagai habitat satwa dan biota.

\section{SIMPULAN DAN SARAN}

Tingkat persepsi pada HK berada pada kategori tinggi, masyarakat sadar akan penetingnya fungsi mangrove. Masyarakat ikut serta menjaga dan bertanggung jawab atas keberlangsungan mangrove, sebagai mana yang di sampaikan oleh petuah-petuah desa mereka. Disamping itu masyarakat juga memiliki kelompok masyarakat yang berperan aktif dalam menjaga kelestarian ekosistem mangrove. Adapun faktor internal yang berpengaruh dengan persepsi yaitu umur, jarak tempat tinggal, Pendapatan dan jumlah tanggungan. Saran selanjutnya ialah perlu dilakukan edukasi lebih lanjut terutama untuk masyarakat yang lama melakukan kegiatan di luar wilayah desa baik itu melanjutkan pendidikan ataupun bekerja.

\section{DAFTAR PUSTAKA}

Agam W. 2016. Tingkat Pengetahuan Masyarakat Sekitar TWA Sibolangit Kabupaten Deli Serdang.

Arikunto S. 1998. Prosedur Peneitian Suatu Pendekatan Paktek. Cetakan ke 11.Jakarta: PT Rineka Cipta.

Budiarti S. 2011. Persepsi dan Partisipasi Masyarakat Desa Sekitar Hutan Terhadap Sistem PHBM di Perum Perthutani. (skripsi). Bogor (ID): Fakultas Kehutanan Institut Pertanian Bogor.

Heru S. 2017. Sikap Dan Persepsi Masyarakat Terhadap Konservasi Mangrove Di Sulawesi Selatan PulaunTenakeke.

Mimi S. 2014. Karakteristik Dan Sosial Ekonomi Lanskap Hutan Pada DAS Kritis dan DAS Tidak Kritis 
Nesmi. 2017. Sikap Masyarakat Sekitar Kawasan Marunda Terhadap Restorasi Ekologi Hutan Mangrove Di Kelurahan Marunda Kecamatan Cilincing Jakarta Utara.

RakhmatJ 2005. Psikologi Komunikasi. Bandung (ID) : PT Remajja Rosdakariya.

Reksohadiprodjo, S., Brodjonegoro. 2000. Ekonomi Lingkungan. BPFE

Sari, H. J. 2012. Kerusakan hutan mangrove di Desa Lubuk Kertang Kecamatan Brandan BaratKabupaten Langkat.

Sarwono J. 2006. Analisis Data Menggunakan SPSS 13. Bandung (ID): Andi Media

Suharjito, Didik, 2000, Pengelolaan Hutan Berbasis Masyarakat, Pustaka Jaya, Jakarta.

Surati. 2014. Analisis Sikap dan Perilaku Masyarakat Terhadap Hutan Penelitian Sosial dan Ekonomi Kehutanan. 